\title{
DEGRADASI AGRARIS SEBAGAI IDE PENCIPTAAN FURNITURE CAFE
}

\author{
Prasetiyo Yunianto *)
}

\begin{abstract}
The creation of this art work is based on the response to the agrarian degradation phenomenon in Indonesia, in the case of the decrease of the farmer number and the field area, and the modernity pressure problem among the farmers. The material used on this work is wood and metal which are created by welding and working seat technique with finishing wax. This art work is created to be functional furniture by using furniture café as the object to deliver the message and critic trough the concept of agrarian degradation phenomenon in Indonesia. The target audience of this art work is young college students. This art work creation is expected to be able to wake the people's awareness toward the agrarian degradation occurs in the society and the young generation as the agent of change is hopefully can respond the phenomenon positively.
\end{abstract}

Keyword : Agrarian, degradation, idea, furniture, cafe

\section{ABSTRAK}

Penciptaan karya ini berlatar atas respon terhadap fenomena degradasi agraris di Indonesia, berkurangnya jumlah petani dan lahan tanam serta permasalahan himpitan modernitas dikalangan masyarakat petani. Material yang digunakan adalah kayu dan logam, menggunakan teknik welding dan teknik kerja bangku, dengan finishing wax. Tujuan dari penciptaan karya ini berfungsi sebagai furniture murni dan juga menciptakan karya seni dengan menggunakan furniture cafe sebagai objek karya penyampai pesan, kritik dengan konsep fenomena degradasi agraris di Indonesia. Target audience dari penciptaan karya ini adalah masyarakat muda mahasiswa. Dari penciptaan karya ini diharapkan mampu menggugah kesadaran masyarakat atas fenomena degradasi agraris yang terjadi dimasyarakat, sehingga masyarakat muda sebagai agen perubahan dapat menyikapinya dengan respon positif.

Kata kunci : degradasi, agraris,ide, furniture, cafe

\footnotetext{
* Prasetiyo Yunianto (prasetiyoyunianto@gmail.com), Mahasiswa Program Penciptaan dan Pengkajian Seni Pascasarjana Institut Seni Indonesia Yogyakarta
} 


\section{PENDAHULUAN}

\section{Sepenggal fenomena degradasi agraris}

Negara Indonesia adalah sebuah Negara yang memiliki banyak sumber daya alam, salah satunya adalah anugerah yang berupa wilayah tropis yang mana kondisi alam tersebut secara alami membentuk aktifitas masyarakatnya dalam ruang lingkup kegiatan yang berhubungan dengan kegiatan agraris, sebab kondisi alamnya sangat tepat untuk digunakan sebagai lahan bercocok tanam. Indonesia adalah Negara yang mayoritas penduduk dipedesaan berprofesi bercocok tanam. Hal ini dikarenakan iklim dan struktur Indonesia yang sangat mendukung untuk bertani. Selain itu lahan yang luas juga menjadi alasan kenapa indonesia disebut negara agraris. Pada era erde baru, sebagian besar masyarakat diluar perkotaan berprofesi sebagai petani dan di dukung oleh pemerintah hingga mencapai swasembada pangan. Pada tahun 2013, sepuluh tahun pasca orde baru jumlah rumah tangga petani adalah 26,13 juta dari tahun 2012 yang berjumlah 31,17 juta, artinya ada penurunan 1,75 \% pertahun.(Tempo, 2, September 2013).

Terdapat beberapa faktor penyebabnya diantaranya adalah biaya untuk bercocok tanam dengan hasil yang di panen tidak sebanding, bahkan bisa terus mengalami kerugian sehingga para petani cenderung lebih memilih menjual lahannya dengan harga yang menurut pandangan petani menguntungkan, padahal untuk jangka panjang justru berpengaruh terhadap siklus perkembangan dan kehidupan para petani itu sendiri dan berpengaruh kepada masyarakat secara umum.

Fenomena yang menjadi penyebab ialah terjadi alih fungsi lahan pertanian menjadi daerah sentra industri atau pemukiman. Program revolusi hijau yang diselenggarakan pemerintah mengabaikan kepemilikan dan penguasaan lahan pertanian. Banyak kebijakan pemerintah yang tidak pro pada sektor pertanian, salah satunya dengan mengkonversi lahan pertanian menjadi daerah industri, pelebaran jalan, pembuatan perumahan dan real estate, lapangan golf, pembangunan DAM, serta sektor non pertanian lainnya. (Kompas, 28 oktober 2013.

Indonesia saat ini menjadi salah satu importir produk pangan terbesar di dunia, pemerintah lebih memilih impor karena harga yang lebih murah. Indonesia tidak lagi mampu berswasembada beras, petani pun merana karena terkena imbas dari mahalnya pupuk. Penurunan dari masa ke masa ini, baik dari jumlah petani dan hasil pertanianya adalah sebuah fenomena yang penting untuk dipelajari lebih lanjut, berawal dari ketertarikan inilah penulis menciptakan karya dengan tema fenomena degradasi dan pemerosotan jumlah lahan pertanian dan hal-hal yang bertalian dengan petani dengan beberapa permasalahan yang menghimpitnya, penulis menciptakan karya instalasi dengan mempresentasikan permasalahan yang paling krusial yang dihadapi para petani yaitu berkurangnya lahan pertanian, penulis mempresentasikan objek cakar ayam dan besi besi beton sebagai penanda penyerbuan property pembangunan di lahan persawahan, secara detail penulis 
bermaksud mengkritisi fenomena ini dalam karya yang penulis hadirkan, gambar dibawah ini sebagai gambaran sepenggal fenomena degradasi agraris.

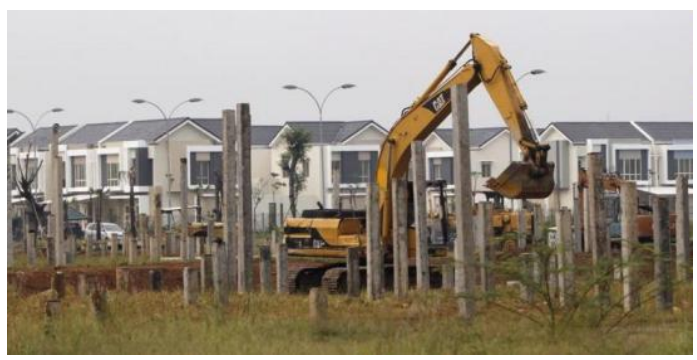

Gambar 1. Pembangunan Property di Lahan Persawahan.

(Sumber: http://properti.kompas.com akses 2 februari 2014)

\section{PEMBAHASAN}

Habit Masyarakat Muda, Café, dan Kepedulian Sosial.

Masyarakat muda sebagai generasi penerus bangsa diharapkan mampu memberikan kontribusi solusi merespon fenomena degradasi agraris di Indonesia, dalam hal ini penulis memulai dengan mengamati kebiasaan para mahasiswa dalam menjalani aktivitas sehari-hari. Kebiasaan masyarakat muda dikalangan mahasiswa kini lebih banyak menggunakan waktunya dengan melakukan aktivitas berdiskusi diruang-ruang nyaman diluar ruang akademik kampus, mahasiswa kini lebih memilih ruang-ruang serupa café untuk melakukan diskusi-diskusi dengan suasana yang tidak terikat aturan akademik. Café-café mulai bermunculan dan mengalami perkembangan yang pesat jumlah dan konsep ruang café tersebut. Ruang ruang café yang ada kini memiliki desain furniture yang beragam menyesuaikan dengan konsep café yang ada, terdapat beberapa café dengan konsep desain furniture minimalis, konsep vintage, konsep strret art, konsep elegant dan lain-lain. Penulis mengamati hal tersebut dan muncul ide untuk menggunakan ruang-ruang café yang notabene merupakan ruang favorit mahasiswa untuk melakukan aktivitas diskusi, untuk menempatkan karya yang berupa furniture café, dari pengamatan itulah penulis menciptakan set furniture café dengan visual furniture yang dapat menggugah kesadaran dan kepedulian mahasiswa terhadap fenomena degradasi agraris. Gambar dibawah ini menunjukan aktivitas mahasiswa yang tengah berdiskusi di ruang café sebagai tempat yang nyaman dan bebas dari dunia akademik.

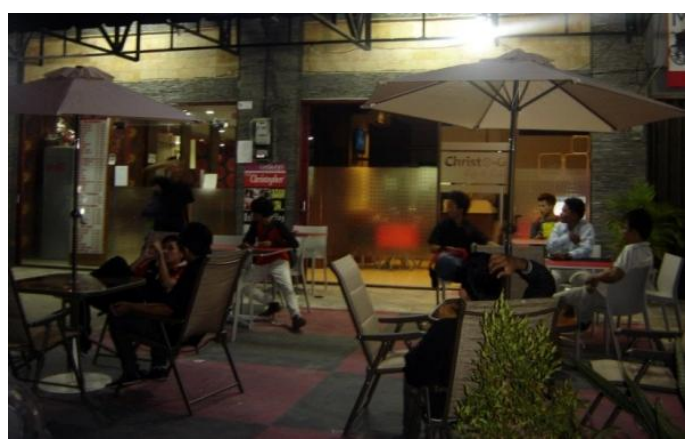

Gambar 2. Suasana Diskusi Mahasiswa di RuangRuang Café, Sebagai Acuan.

(Sumber : http/cristogcafe.wodpress.com)

Dari uraian di atas, penulis mencoba bagaimana menciptakan karyakarya furnitur café yang berdasar atas fenomena degradasi agraris di Indonesia, serta bagaimana memasukan pesan, nilai, serta muatan kritik sosial dalam karya seni furniture yang diciptakan terkait dengan tematik yang tepat mengatasi degradasi agraris Indonesia. Sementara tujuan dari penciptaan karya ini adalah menciptakan karya seni furniture caffe sebagai media 
kritik dan respon positif atas fenomena dalam dunia pertanian serta degradasi lahan agraris di Indonesia. Manfaat dari penciptaan karya ini ialah untuk menggugah kesadaran masyarakat muda mahasiswa atas fenomena kebudayaan, dalam hal ini degradasi agraris yang dari karya tersebut masyarakat muda mahasiswa dapat menyikapinya dengan respon positif.

Dalam proses penciptaan karya ini digunakan pendekatan fenomenologi. Pendekatan fenomenologi merupakan tradisi penelitian kualitatif yang berakar pada filosofi dan psikologi, dan berfokus pada pengalaman hidup manusia (sosiologi). Pendekatan fenomenologi hampir serupa dengan pendekatan hermeneutik yang menggunakan pengalaman hidup sebagai alat untuk memahami secara lebih baik tentang sosial budaya, politik atau konteks sejarah dimana pengalaman itu terjadi. Penelitian ini akan berdiskusi tentang suatu objek kajian dangan memahami inti pengalaman dari suatu fenomena. Peneliti akan mengkaji secara mendalam isu sentral dari struktur utama suatu objek kajian dan selalu bertanya "apa pengalaman utama yang akan dijelaskan informan tentang subjek kajian penelitian". Peneliti memulai kajiannya dengan ide filosofikal yang menggambarkan tema utama. Translasi dilakukan dengan memasuki wawasan persepsi informan, melihat bagaimana mereka melalui suatu pengalaman, kehidupan dan memperlihatkan fenomena serta mencari makna dari pengalaman informan. Peneliti dalam pandangan fenomenologis berusaha memahami arti peristiwa dan kaitan-kaitannya terhadap orang-orang biasa dalam situasi-situasi tertentu. Sosiologi fenomenologis pada dasarnya sangat dipengaruhi oleh pandangan Edmund Husserl dan Alfred Schultz. Pengaruh lainnya berasal dari Weber yang memberi tekanan pada verstehn, yaitu pengertian interpretatif terhadap pemahaman manusia. Fenomoenologi tidak berasumsi bahwa peneliti mengetahui arti sesuatu bagi orang-orang yang sedang diteliti oleh mereka. (Moleong, Lexy J.2007.)

Inkuiri fenomenologis memulai dengan diam, diam merupakan tindakan untuk mengungkap pengertian sesuatu yang sedang diteliti. Hal yang ditekankan oleh kaum fenomenologis adalah aspek subjektif dari perilaku orang. Mereka berusaha untuk masuk kedalam dunia konseptual para subyek yang ditelitinya sedemikian rupa sehingga mereka mengerti apa dan bagaiaman suatu pengertian yang dikembangkan oleh mereka di sekitar peristiwa dalam kehidupannya sehari-hari. Para fenomenolog percaya bahwa pada makhluk hidup tersedia pelbagai cara untuk menginterpretasikan pengalaman melalui interaksi dengan orang lain, dan bahwa pengertian pengalaman kitalah yang membentuk kenyataan. (Moleong, Lexy J.2007.)

Dalam proses pendekatan fenomenologi ini, penulis melakukan pendekatan langsung pada objek dan pelaku, dalam hal ini petani, dan juga melakukan wawancara dengan masyarakat muda mahasiswa. Pengamatan dan pendalaman dilakukan dengan mencari sampel lahan-lahan yang secara kasat mata mengalami jumlah penurunan kwantitas, 
juga mengamati lahan-lahan pertanian yangdilahan tersebut sedang di bangun perumahan ataupun bangunan pertokoan dan lain-lain, pengamatan dilakukan diseputaran daerah provinsi Daerah Istimewa Yogyakarta yakni meliputi kabupaten Bantul, Sleman, Kulonprogo, Wonosari dan Kota Yogyakarta. Selain itu penulis juga melakukan perbandingan dengan wilayah kabupaten Klaten sebagai salah satu daerah unggulan penghasil beras terbaik di Indonesia.

Penulis melakukan wawancara langsung dengan para petani mengenai permasalahan-permasalahan yang dihadapi petani, juga melakukan wawancara dengan beberapa kontraktor property sebagai bahan perbandingan mengenai bagaimana sudut pandang penggunaan lahan pertanian aktif yang dijadikan lahan pembangunan dan perluasan property.

Dari hasil pengamatan tersebut penulis mendapatkan beberapa informasi akurat yang dijadikan penulis sebagai ide dalam penciptaan karya, hal itu antara lain adalah permasalahan ekonomi yang dialami para petani sehingga mau tidak mau kondisi ekonomi yang rendah akan memaksa petani menjual lahanya untuk bertahan hidup, sebab bertahan hidup lewat jalan bertani semakin lama semakin tidak dapat diandalkan.

Metode pendekatan yang kedua adalah pendekatan Estetis, yaitu metode yang mengacu pada nilai-nilai estetis yang terkandung dalam seni rupa seperti garis, warna, tekstur, irama, ritme, bentuk, sebagai pendukung dalam pembuatan karya. Pendekatan estetis, bertujuan agar karya yang akan dibuat memperoleh keindahan dan mempunyai satu ciri khas. Dalam pembuatan karya ini terdapat tiga unsur estetik yang mendasar, yaitu: keutuhan atau kebersatuan (unity), penonjolan atau penekanan (dominance), keseimbangan (balance). ( A.A.M. Djelantik., 2004). Unsur kebersatuan, penekanan, dan keseimbangan diujudkan dengan mengelaborasikan objek-objek yang saling berhubungan.

Dalam karya ini, penulis secara detail mempertimbangkan unsur-unsur keseimbangan, penulis menghadirkan beberapa objek berupa tiang beton cakar ayam sebahai objek utama dengan menggunakan elemen objek tanaman padi. Material yang digunakan juga terdapat dua jenis, yaitu material kayu serta material logam besi. Dua material ini dihadirkan dengan pertimbangan keseimbangan material untuk menghindari kemonotonan material.

Ketiga adalah pendekatan semiotika, yaitu menginterpretasikan bentuk visual ke dalam sistem tanda dan simbol. Keberadaan semiotika tidak dapat dilepaskan dalam proses penciptaan karya seni. Semiotika dipergunakan untuk lebih memperjelas maksud yang ingin disampaikan seniman kepada penikmatnya. Semiotika merujuk kepada "ilmu atau metode analisis untuk mengkaji tanda, yaitu perangkat untuk mencari jalan di tengah-tengah manusia dan bersamasama manusia lainnya." (Alex Sobur, 2003)

Dalam karya ini, penulis menghadirkan karya dengan penataan instalasi furniture, sebuah kesatuan dari objek meja dan kursi yang ditata sehingga membentuk tatanan yang saling berhubungan dan membentuk sebuah 
tema cerita yang utuh dan menyatu. Dalam instalasi furniture ini tiap objek dihadirkan sebagai penanda-penanda yang dihadirkan untuk mewakili kandungan makna didalam objek masing-masing.

Mengenai tanda ini Charles Sanders Peirce mengklasifikasikan tanda berdasarkan hubungan representamen dengan objeknya ke dalam tiga kelompok, yaitu ikon (icon), indeks (index), dan simbol (symbol). Ikon adalah tanda yang didasarkan atas "keserupaan" atau "kemiripan" (resemblance) di antara representamen dan objeknya, entah objek tersebut betul-betul eksis atau tidak. Indeks adalah tanda yang memiliki kaitan fisik, eksistensial, atau kausal di antara representamen dan objeknya sehingga seolah-olah akan kehilangan karakter yang menjadikannya tanda jika objeknya dipindahkan atau dihilangkan. Simbol adalah tanda yang representamennya merujuk kepada objek tertentu tanpa motivasi (unmotivated); simbol terbentuk melalui konvensi-konvensi atau kaidahkaidah, tanpa adanya kaitan langsung di antara representamen dan objeknya. (Kris Budiman, Ikonitas: Semiotika Sastra dan Seni Visual, Yogyakarta: Penerbit Buku Baik, 2005).

Objek yang dihadirkan adalah objek cakar ayam dari material besi sebagai penanda dimulainya proses penyerangan lahan pembangunan property kelahan aktif pertanian. Objek lain yang dihadirkan adalah buah padi yang dibuat dari material besi sebagai penanda bahwa petani telah kehilangan padi karena tergantikan besibesi beton sebagai bahan tanam disawah, tidak lagi tanaman padi, namun yang terjadi adalah tanaman besi.
Dengan menggunakan teori Charles Sanders Peirce di atas, tanda-tanda yang berhubungan dengan fenomena degradasi masyarakat agraris diterapkan dalam karya. Ikon-ikon dimasukan sebagai unsur penting dalam karya yang pada akhirnya semua tanda-tanda yang terklarifikasi atas unsur ikon, indeks, dan simbol ini menjadi sebuah unsur penanda yang baru karena ketiga tanda di atas telah membentuk makna dan tanda baru setelah mengalami elaborasi tanda dalam setiap karya.

\section{Metodologi Penciptaan Karya}

Metode penciptaan yang digunakan penulis sebagai pedoman dalam penciptaan karya ini meminjam pendapat Sp. Gustami dalam tulisannya yang berjudul "Trilogi Keseimbangan", Ide dasar penciptaan seni kriya untaian metodologis, yang menyatakan :

Dalam konteks metodologis terdapat tiga tahap penciptaan seni kriya yaitu eksplorasi, perancangan dan perwujudan. Tahap eksplorasi meliputi aktivitas penjelajahan menggali sumbersumber ide dengan langkah identifikasi dan perumusan masalah secara teoritis, yang hasilnya dipakai sebagai dasar perancangan. Tahap perancangan yang dibangun berdasarkan perolehan butir penting hasil analisis yang dirumuskan, diteruskan visualisasi gagasan dalam bentuk sketsa alternatif, kemudian ditetapkan pilihan sketsa terbaik sebagai acuan reka bentuk atau dengan gambar teknik yang berguna bagi perwujudannya. Tahap ketiga yaitu perwujudan, bermula dari pembuatan model sesuai sketsa alternative atau gambar teknik yang telah 
disiapkan menjadi model prototype sampai ditemukan kesempurnaan karya yang dikehendaki (Gustami, SP , 2008)

Langkah-langkah perencanaan secara seksama, analitis, dan sistematis dilakukan agar tidak terjadi keliaran ekspresi dalam proses perwujudan, tahapan-tahapan tersebut dapat diuraikan sebagai berikut:

\section{Eksplorasi}

Eksplorasi yang dimaksudkan adalah pencarian tema penciptaan yang dilakukan melalui pengamatan langsung pada fenomena dan peristiwa yang terjadi dimasyarakat yang berhubungan dengan tematik, salah satunya dengan melakukuan wawancara dengan para petani mengenai pergeseran pandangan masyarakat terhadap pentingnya pertanian di masyarakat.

Sebagai langkah awal eksplorasi, salah satu wacana yang penulis berusaha gali adalah mengenai kenapa terjadi fenomena pengurangan lahan dan menurunya jumlah petani serta masalah masalah yang dialami para petani sekarang ini, ada beberapa faktor diantaranya, para petani yang mengeluhkan kalau biaya untuk bercocok tanam dengan hasil yang di panen tidak sebanding, bahkan bisa terus merugi sehingga mereka cenderung lebih memilih menjual lahannya dengan harga yang menurut mereka menguntungkan, namun untuk jangka panjang justru berpengaruh terhadap siklus perkembangan dan kehidupannya. Selain hal diatas para petani juga mengutarakan mengenai anomali cuaca, kemudian pergeseran paradigma pemuda dalam memandang pertanian. Dalam hal ini penulis juga melakukan wawancara kepada mahasiswa untuk pembanding pandangan mengenai fenomena degradasi agraris.

\section{Perancangan}

Ide atau gagasan dari hasil analisis yang dilakukan selanjutnya dituangkan ke dalam bentuk visual dalam batas rancangan dua dimensional. Perancangan ini dilakukan dengan mempertimbangkan aspek material, teknik, proses, metode, kontruksi, keseimbangan, bentuk, unsur estetik, gaya, filosofi, pesan, makna, fungsi sosial dan budaya, serta peluang ke depannya. Dalam penggunaan material disesuaikan dengan bentuk dari rancangan gambar. Dengan mengumpulkan beberapa contoh desain furniture café seperti gambar di bawah ini sebagai acuan dan pembanding untuk menciptakan karya yang relative baru dan memiliki nilai kebaruan dalam ide. Dalam perancangan ini penulis membuat terlebih dahulu desain berupa gambar, kemudian mewujudkan desain berupa prototype sebagai acuan yang nantinya akan diwujudkan dalam bahan kayu dan besi.

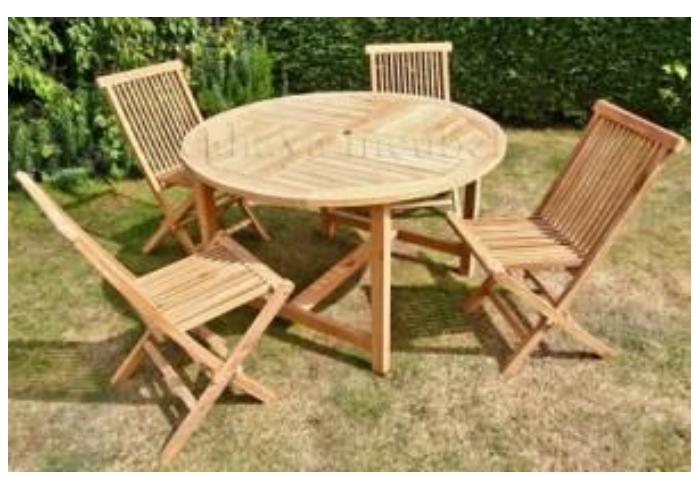

Gambar 3. Jenis Furnitur Kursi Lipat Gaya Minimalis di Atas Adalah Jenis Yang Paling Banyak Digunakan untuk Mengisi ruang café sebagai bahan acuan pembuatan karya. (Foto: Prasetiyo Y, 2014 ) 


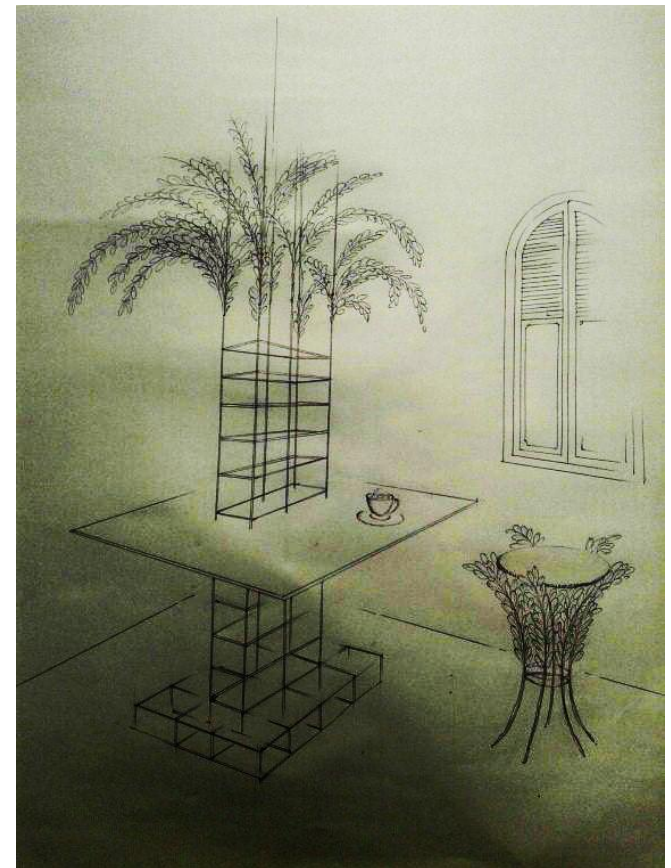

Gambar 4. Rancangan Desain Set Furniture Café (Foto: Prasetiyo Y, 2014)

\section{Perwujudan}

Setelah alternatif-alternatif rancangan/sketsa yang telah dibuat kemudian dipilih dan ditentukan rancangan mana yang terbaik untuk dibuatkan gambar teknik berikut kelengkapannya. Tahap perwujudan dilaksanakan berdasarkan gambar teknik yang telah dibuat dan dianggap sempurna, kemudian pengerjaan. Pengerjaan karya dimulai prototype dengan bahan kayu, proses ini dilakukan dengan teknik kerja bangku, dengan menggunakan system responsiblel dalam perwujudanya dengan tetap mengacu pada rancangan utamanya sehingga bentuk keseluruhan tetap sama.

Proses kedua adalah pembuatan objek cakar ayam dan tanaman padi yang keduanya terbuat dari material besi, proses ini dilakukan dengan teknik las welding dengan menggunakan materialbesi eser ukuran $0,1 \mathrm{~cm}$, dan ukuran $0,6 \mathrm{~cm}$. proses dalam pengelasan ini diikuti dengan penambahan artistic dengan menambahkan pembuatan buah padi dibeberapa bagian ujung atas objek tiang cakar ayam.

Proses terakir adalah proses konstruksi dan perakitan, top meja digabung dengan konstruksi sambungan knock dwon, kemudian setelah tersambung maka proses terakir adalah seting display instalasi dalam ruang display atau ruang cafe, dalam proses ini penulis tetap menggunakan desai rancangan awal sebagai panduan utama dengan bentuk penataan karya instalasi lebih banyak menggunakan pertimbangan estetika dan keseimbangan. Proses evaluasi dilakukan setelah karya furniture selesai proses display sebagai bahan koreksi dari keseluruhan proses untuk dinilai sejauhmana pencapaian karya.

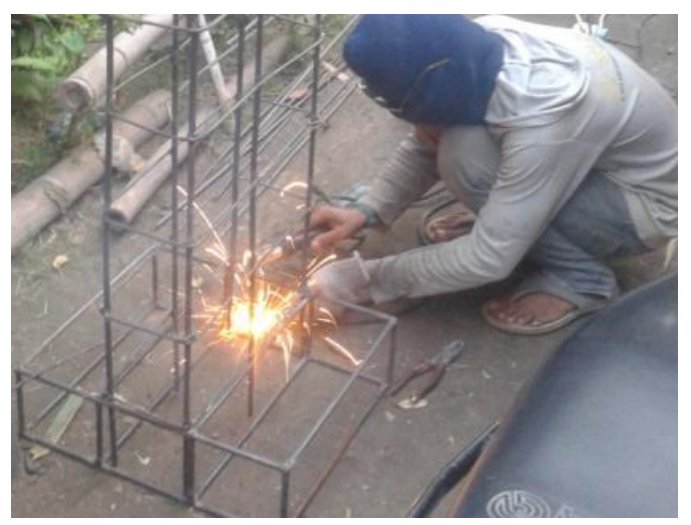

Gambar 5. Proses Pembuatan Meja Dengan Konstruksi Besi Dengan Teknik Welding. (Foto: Prasetiyo Y, 2014)

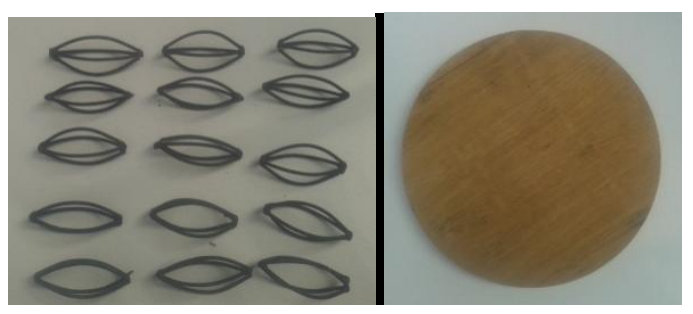


Gambar 6. Rangkaian Bahan Objek Padi Dari Besi Eser dan Papan Kayu Untuk Daun Meja dan Kursi (Foto: Prasetiyo Y, 2014)
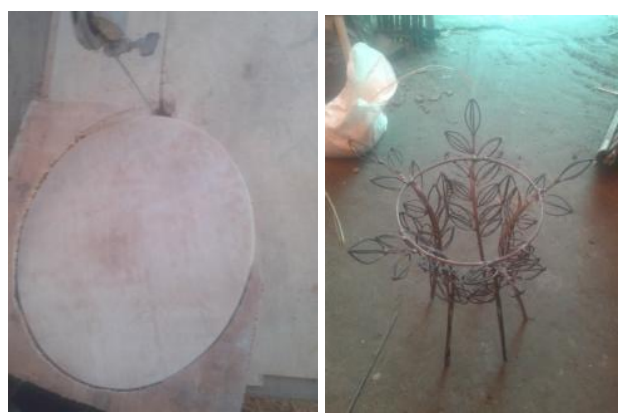

Gambar 7. Proses Pemotongan Daun Kursi dan Meja Dari Kayu dan Perakitan Kursi

(Foto: Prasetiyo Y, 2014)

\section{Skema Proses Kreatif Penciptaan Karya Seni furniture Café.}

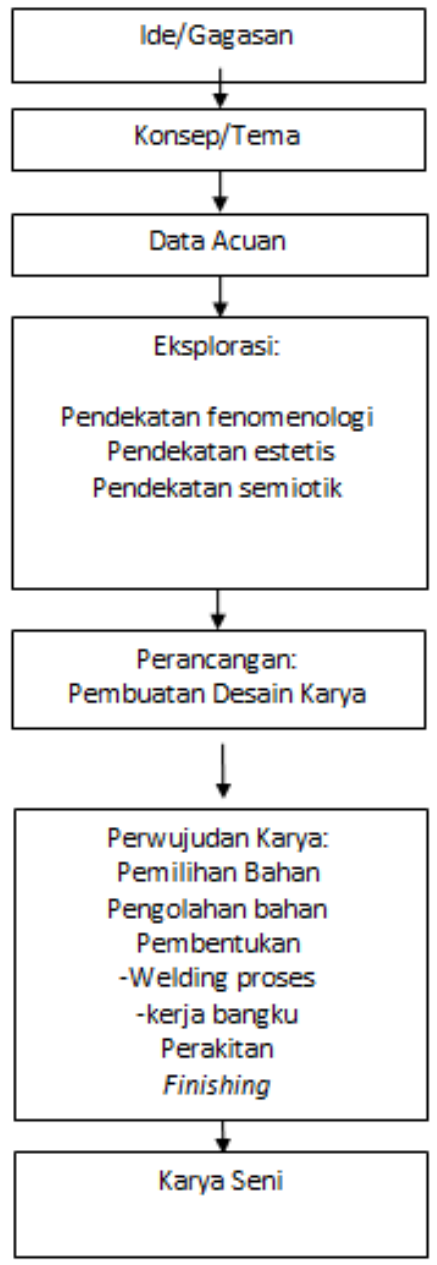

\section{PENUTUP}

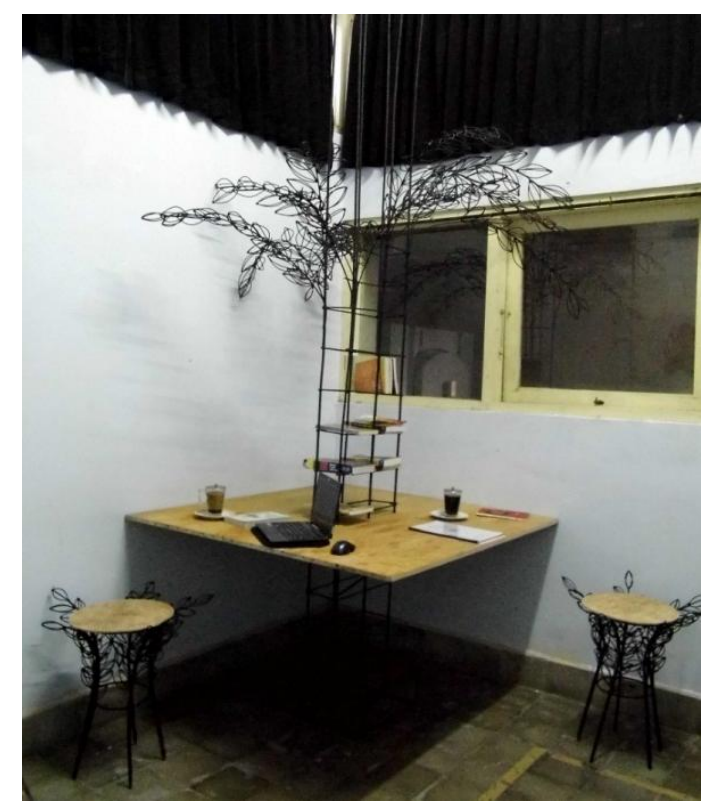

Gambar 7. Hasil akir karya furniture café.

(Foto: Prasetiyo Y, 2015)

Karya furniture café ini berjudul “ degradasi agraris", dengan bahan besi dan kayu, objek berupa tiang dengan konstruksi cakar ayam sebagai objek utama karya ini, tiang besi menyangga daun meja dan pada ujungnya mengeluarkan buah padi bergerombol, meja ini berfungsi praktis sebagaimana meja pada umumnya, tiang besi juga berfungsi sebagai rak buku yang disusun bertingkat. Dari mata pandang ilmu tanda, tiang besi mewakili serbuah pembangunan yang dihadapi masyarakat setiaphari tanpa henti didepan mata kita, lahan sawah tidak lagi tumbuh padi namun tumbuh tiang-tiang besi, dalam karya ini tiang besi berbuah padi, kritik atas serbuan pembangunan property yang tumbuh subur seperti padi yang tumbuh subur sebelumnya. Visual kursi berupa padi yang diikat, seperti halnya ikatan padi setelah panen, kursi ini juga berfungsi praktis sebagai tempat duduk. Dalam mata pandang semiotika kita setiap hari duduk di 
atas padi, artinya apapun yang kita lakukan setiap hari tidak dapat dipungkiri bahwa sumber pokok pangan kita adalah padi.

Karya ini di display atau di tempatkan pada ruang café dengan sasaran utamanya masyarakat muda mahasiswa, sebagai egen perubahan masa depan maka setidaknya karya ini mampu mengusik fikiran para mahasiswa pengguna café untuk memberikan sumbangan fikiran mengenai degradasi agraris yang sedang terjadi.

\section{KEPUSTAKAAN}

Djelantik,A.A.M. 2004. Estetika: Sebuah Pengantar. Bandung: Masyarakat Seni

Pertunjukan Indonesia Bekerjasama dengan Arti.

Gustami, S.P. 2006.“Trilogi Keseimbangan” Ide Dasar Penciptaan Seni Kriya Untaian

Metodologis, dalam Jurnal Dewa Ruci, Volume 4, No. 1, ISI Surakarta, 2004. "Proses Penciptaan Seni Kriya; Untaian Metodologis",

(Yogyakarta: Materi Kuliah Program Pasca Sarjana S2 Penciptaan dan Pengkajian Seni Institut Seni Indonesia)

Kris Budiman. 2005. Ikonitas: Semiotika Sastra dan Seni Visual. Yogyakarta: Penerbit Buku Baik.
Moleong, Lexy J. 2007. Metodologi Penelitian Kualitatif Edisi Revisi. Bandung: PT. Remaja Rosdakarya.

Saidi, Acep Iwan. 2008. Narasi Simbolik Seni Rupa Kontemporer Indonesia.Yogyakarta: Isacbook.

Sobur,Alex. 2003. Semiotika Komunikasi. Bandung: Remaja Rosdakarya.

Koran Tempo, 2 September 2013

Koran Kompas, 28 oktober 2013

Koran Kompas 20 november 2013

Pusat Bahasa Depdiknas ,2008. 